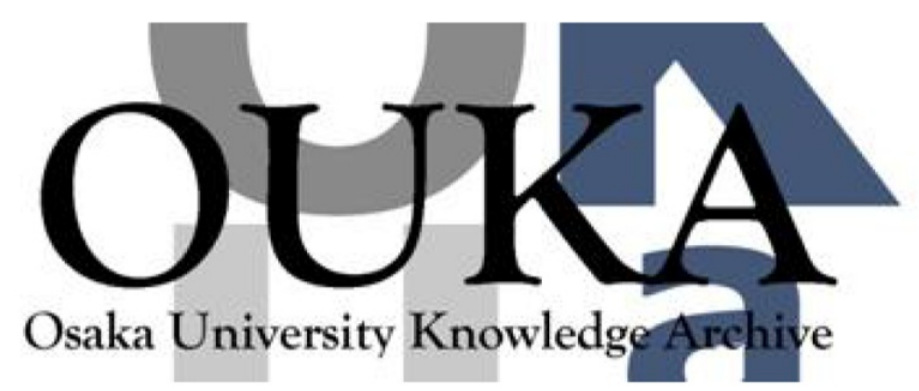

\begin{tabular}{|c|c|}
\hline Title & LZW法に移動空を組み合わせたデータ圧縮方式につい \\
\hline Author (s) & 荻原，剛志; 飯田，元; 井上，克郎 他 \\
\hline Citation & $\begin{array}{l}\text { 電子情報通信学会論文誌A. J76-A(11) p. 1593- } \\
\text { p.1602 }\end{array}$ \\
\hline Issue Date & $1993-11-25$ \\
\hline oaire:version & VoR \\
\hline URL & https://hdl. handle. net/11094/26452 \\
\hline rights & copyright@1993 IEICE \\
\hline Note & \\
\hline
\end{tabular}

Osaka University Knowledge Archive : OUKA

https://ir. Library. osaka-u. ac. jp/

Osaka University 
LZW 法に移動空を組み合わせたデータ圧縮方式について

\begin{tabular}{|c|c|c|c|}
\hline 員 & 荻原 & 剛志 $^{\dagger}$ & 非会員 \\
\hline & & 克郎 ${ }^{\dagger \dagger}$ & 正 \\
\hline
\end{tabular}

\title{
Compression Method Using LZW Coding and a Sliding Window
}

Takeshi OGIHARA ${ }^{\dagger}$, Member, Hajimu IIDA $^{\dagger \dagger}$, Nonmember, Katsuro INOUE ${ }^{\dagger \dagger}$ and Koji TORII ${ }^{\dagger \dagger}$, Members

\begin{abstract}
あらまし データ圧縮法として広く利用されているLZW 法に数 kByte 程度の移動空 (sliding window) 付 加し，移動空中で一致した文字列の長さを LZW 符号の代わりに符号化することによって圧縮効率を向上させる 方法を提案する。この方式では, LZW 法のフレーズを構成する際, 移動空内でのそのフレーズの位置を記録して おく、この情報を利用すると，新しく構成される LZW 法のフレーズが既に移動空内にあることがすかる場合があ る. 新たな入力文字列が LZW 法のフレーズより長く移動空内の文字列と一致する場合, LZW 符号の代わりに一 致する文字列の長さを符号化する。この方式忟, 大部分の圧縮対象について LZW 法の結果を改善するほか, 他の $\mathrm{LZW}$ 法の改良アルゴリズムと同等以上の性能を示す. 処理時間も $\mathrm{LZW}$ 法に比べて $25 \%$ 程度の増加にとどまり， 実用性の高い压縮法である。
\end{abstract}

キーワード データ圧縮，無ひずみ压縮，LZW 法，移動空

\section{1. まえがき}

データ圧縮アルゴリズムとして，さまざまな方式が 提案・研究されているが，何を圧縮対象とするのか， あるいは処理速度，圧縮率，必要なメモリ量のどれを 重視するのかによって，さまざまな選択肢がある(1),(2). その中でも Ziv と Lempel の提案したインクリメンタ ル分解 ${ }^{(3)}$ の実現の一つである LZW (Lempel-ZivWelch）法(4) は，入力の性質に依存しない（ユニバー サル性)，高速，高压縮の実用的な無ひずみ圧縮アルゴ リズムとして著名である，LZW 法はすべての点につ いて他の方法より優れているというわけではないが， 処理時間と压縮能率のバランスという点で最も強力か つ実用的なアルゴリズムの一つであると言うことがで きよう.

しかし LZW 法は, 出現回数が多くない文字列は, そ

$\dagger$ 大阪大学情報処理教育センター, 豊中市

Education Center for Information Processing, Osaka University, Toyonaka-shi, 560 Japan

†† 大阪大学基礎工学部情報工学科, 豊中市

Faculty of Engineering Science, Osaka University, Toyonakashi, 560 Japan

†† 奈良先端科学技術大学院大学情報科学研究科, 生駒市

Graduate School of Information Science, Nara Institute of Science and Technology, Ikoma-shi, 630 Japan
れが長ければ長いほど，直ちには効率の良い圧縮がで きないという欠点をもつ．これは文字列の置換による 符号化方式(5)(以下では LZ 77 法と呼ぶ) と比較した場 合に顕著である。この欠点を補うため, LZW 法の辞書 の成長速度を加速する改良方式(6) がいくつか提案さ れているが，辞書が飽和する時期も早くなるため，入 力長が大きい場合には効果が薄い.

一方, LZ 77 法に基づく圧縮法は，置換文字列の符号 化などを工夫することによって高い圧縮能力を実現で きるが, 移動空（sliding window）から最長く一致 する文字列を発見する部分が処理効率を畺化させてい る.

本論文では，LZW 法に数 $\mathrm{kByte}$ 程度の移動空を付 加し，移動空の中で一致した文字列の長さを LZW 符 号の代わりに符号化する新しい符号化方式とそのアル ゴリズムを提案する。この方法によって上記の欠点を 解消し，厈縮能力を向上できることを示す．この方式 は LZW 法と LZ 77 法の特徴を併せもち，幅広い種類 の入力に対して高い圧縮能力を発揮する. LZW 法と 文字列置換の融合方式であるため，コニバーサル性は 保持している。またこのアルゴリズムは LZW 法と同 椂，入力長に対する線形時間で処理を行い，移動空の サイズが実行速度に影響しないという特徴も備えてい 
る. 処理時間は LZW 法に比べて $25 \%$ 程度の増加にと どまる。

本方式は LZW 法の高速な処理速度という特長を残 しつつ，圧縮効率を向上させることが可能である．従 って，現在 LZW 法が用いられている多くの局面に対 して実用的に適用が可能であると考えられる。また， 移動悹の付加という手法はいくつかの LZW 法の改良 方式に詨しても同様に適用が可能であり，更に压縮率 を改善することが見込める。

以下では，新たな符号化方式とアルゴリズムについ て述べ，圧縮能力に関する実験の結果から，本方式が LZW 法の改良として実用的な方式であることを示 す.

\section{LZW 法と LZ77 法}

\subsection{LZW 法の検討}

$\mathrm{LZW}$ 法による圧縮アルゴリズムのあらましをC 言 語の構文を用いて記述したものを図 1 に示す。ここで は，通常の文字はそ机自体の文字コードを符号とし， 新たに登録される文字列（フレーズ）には文字コード 以上の整数値を逐一割り当てて符号とする。これは UNIX のツールである compress などの採用してい る方法である。

関数 InputChar（） 1 文字の読込み, OutputBits (str) は符号 strの書出しを表す。また, Search(str， ch) 缼号 str と文字 $c h$ から構成されるフレーズが既 に辞書に登録されていればその符号を返し，まだ登録 されていない場合にはUNUSED（符号として用いな い值）を返す. Update (str, ch) は，符号 $s t r$ と文字 chから構成される新しいフレーズを辞書に登録する.

LZW 法では，長さ $n$ の文字列がフレーズとして登

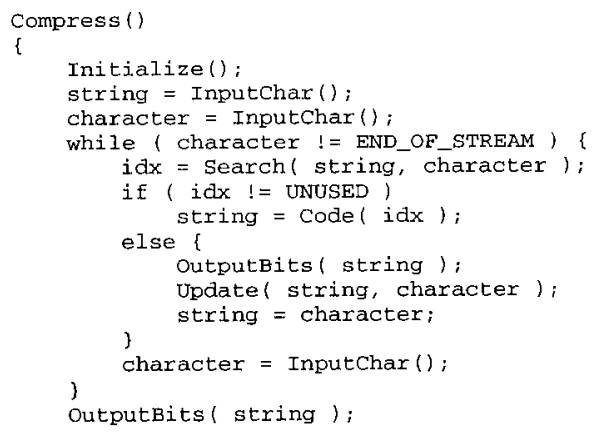

図 1 LZW 法のアルゴリズム Fig. 1 LZW algorithm.
録されるまでに（同じ部分文字列をもつ別の文字列の 存在を仮定しなければ) $(n-1)$ 回の出現が必要である. このことは，入力列のサイズが小さい場合には十分な 压縮能力が得られないことを意味する。

一般にインクリメンタル分解の圧縮方式では, 辞書 の成長速度を加速することによって圧縮能力を増大で きる。そこで，1文字の入力によって複数のフレーズ を構成するなど，フレーズの構成方法によっていくつ かの改良案が提案され得る。横尾の符号(6),(7), Bernstein $9 \mathrm{Y}$ 符号姑などがその例である。これらの方式 ではサイズの小さな入力列に対しても圧縮能力が向上 しているが, 半面, 辞書が飽和する時期も早くなるた め, ある程度以上の大きさの入力に対しては $\mathrm{LZW}$ 法 と圧縮能力にそれほど差がなくなってくる（4.の実験 結果を参照)。

\subsection{LZ77 法について}

文字列の置換による LZ 77 法に基づく圧縮法は, 移 動空を用い，先行する同じ文字列の位置と長さを符号 として表す，移動空はリングバッファとして実現され ることが多い，この方法では，長い文字列であっても 移動空に存在すれば，先行する文字列を参照する短い 符号として表現できる. 符号化の部分を工夫すること によって高い圧縮能力を実現できる ${ }^{(8)}$.

しかし逆に，比較的短い置換文字列をあまり効率良 く表現できないという問題や，頻繁に出現する文字列 であっても，常に同じ符号でしか表せないという問題 もある・

これらのアルゴリズムでは一般に, 現在の入力と最 も長く一致する文字列を移動空から発見する部分が処 理効率を悪化させている. 移動空の大きさを増加させ るのに従って圧縮能力も増すが，同時に文字列検索の 手間も増大してしまう。このため, 辞書の探索を効率 的に行えるようなデータ構造やアルゴリズムが多数提 案されているが，一般にインクリメンタル分解に基ず く圧縮法よりも多くの処理時間を要する.

\section{3 二つの方式の融合}

上の議論から，LZW 法において辞書にまだ登録さ れていない文字列が入力中に再び出現した場合に, 文 字列置換の手法を利用することが考えられる. 頻繁に 出現する文字列は LZW 符号によって表現し, 出現頻

\footnotetext{
$\dagger$ S. W. Thomas, J. McKie, S. Davies, K. Turkowski, J. A. Woods, and J. W. Orost, Compress (version 4.0) 1985.

林 Daniel J. Bernstein: "Y coding", Draft 4b (Mar. 1991). このテキ スト招よびソフトウェア yabbawhap, version 1.00 (Mar. 1991)は パブリッタドメインに置かれている。
} 
度の少ない文字列に仗文字列置換を適用するのであ る.

このような折孛的な手法を検討する場合に問題とな るのは, 符号化の方法も含め, LZW 符号と文字列置換 をどのように融合させるかということである。さまざ まな考え方があり得るが，本論文では LZW 法が実用 的には核济な分な能力をもっていることを考慮し， LZW 法に補助として文字列置換の機能を取り入れる 方針とした。

\section{3. 新符号化方式}

\section{$3.1 \mathrm{LZW}$ 辞書と移動空}

LZW 法のフレーズは既に辞書に登録されている別 のフレーズともう1文字から構成されるが，以下の議 論では，フレーズ A がフレーズ $\mathrm{B}$ と文字 $\mathrm{c}$ から構成 されているとき，フレーズ $\mathrm{B}$ はフレーズ $\mathrm{A}$ の「親フレ ーズ」，文字 $\mathrm{c}$ はフレーズ A の「付加文字」であると言 うことにする。

$\mathrm{LZW}$ 辞書と移動空は次のようにして関係づける。

今, 新たなフレーズが $\mathrm{L} Z \mathrm{~W}$ 辞書に登録される際に, そのフレーズの付加文字に相当する移動空上の位置 を,フレーズごとに LZW 辞書に登録しておく。また, 新たな入力に伴って LZW 辞書が検索された場合に も，そのフレーズの移動空上の新しい位置を $\mathrm{LZW}$ 辞 書に登録し直す。但し，移動突の大きさ怯有限である 加ら，移動空加ら追い出された文字に関する情報は

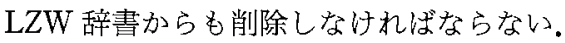

図 2 は文字列“abaabbab”を処理したときの LZW 辞書と移動空の関係である: 破線の矢印法，そのフレ ーズと移動空の古い対応関係労している，例えば， 新しいフレーズ“abb”を登録するときに，既に登録さ れていたフレーズ“ab”の位置も変更される。

これらの操作は，新たに 1 文字入力するでとに 1 回 ずつ行うだけでよい，また，操作の手間は移動空の大 きさには依存しない。

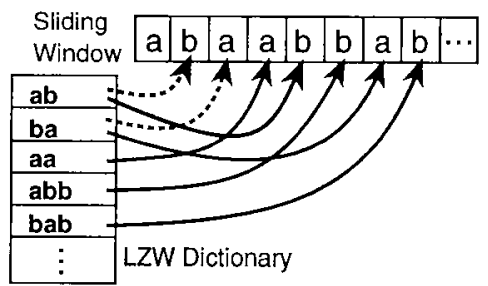

図 $2 \mathrm{LZW}$ 辞書と移動空の対応付け

Fig. 2 LZW dictionary refers to sliding window.

\section{2 アルゴリズム}

アルゴリズムの概略について述べる.

新しいフレーズを $\mathrm{LZW}$ 辞書に登録する際，新しい フレーズの親フレーズが移動空上の位置情報をもつて いたとする。このとき，新しいフレーズの付加文字お よびそれ以降の入力文字を移動突上の文字と順次比較 すれば，LZW 辞書には登録されていない置換文字列 を移動笞加ら発見できる。付加文字も含め，2文学以 上の入力文字が移動空の文字と一致した場合には, 親 フレーズの LZW 符号に続いて，一致した長さを符号 化して出力する。そうでない場合には，通常どおり $\mathrm{LZW}$ 符号化の手順を進める。

入力文字列が移動空の文字列と一致している間，入 力文字列は LZW のフレーズに分解を行い, LZW 辞書 に登録していくが，出力行わない.

例として，“abbabbabbbaa”という文字列符号化 する場合について説明する（図 3 )。先頭を 0 文字目と して 3 文字目まで処理したときの辞書が(a)である. n はフレーズに割り当てられた符号, str はフレーズ, pos はそのフレーズの付加文字の移動空内の位置であ る.4文字目を読み込んだときに構成されるフレーズ は“ab”であるが，これは既に辞書に登録されている。 そこで，次の文字を読み込み，フレーズ“ab”のposの 示す次の位置の文字と比較すると両方“b”である。こ れ以降,フレーズ“ $\mathrm{ab}$ の後ろに引き続く文字と入力文 字が同じである間, LZW 法のフレーズを構成し，辞書 に登録するが，フレーズの符号は出力しない。また， 構成されたフレ一ズについて posの欄の值も更新す 歹.

（b）は８文学目までを処理したときの辞書である. 9 文字目は“b”であるが，これは移動空の対応する文

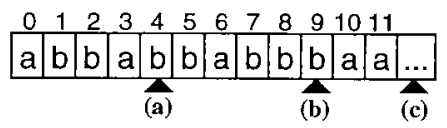

(a)

(b)

(c)

\begin{tabular}{|c|c|c|c|c|c|c|c|c|}
\hline$n$ & str & pos & $n$ & str & pos & $n$ & str & pos \\
\hline $\begin{array}{l}0 \\
1\end{array}$ & $\begin{array}{l}a \\
b\end{array}$ & & $\begin{array}{l}0 \\
1\end{array}$ & $\begin{array}{l}a \\
b\end{array}$ & & $\begin{array}{l}0 \\
1\end{array}$ & $\begin{array}{l}\mathbf{a} \\
\mathbf{b}\end{array}$ & \\
\hline 2 & $a b$ & 1 & 2 & $a b$ & 4 & 2 & $a b$ & 4 \\
\hline 3 & bb & 2 & 3 & bb & 8 & 3 & bb & 8 \\
\hline 4 & ba & 3 & 4 & ba & 6 & 4 & ba & 10 \\
\hline & & & 5 & $a b b$ & 5 & 5 & abb & 5 \\
\hline & & & 6 & bab & 7 & 6 & bab & 7 \\
\hline & & & & & & 7 & baa & 11 \\
\hline
\end{tabular}

図 3 符号化の例

Fig. 3 An example of coding. 
字 (6 文字目の“a”) と一致しない.そこでここまで 一致した文字数の 4 符号化して出力し,これ以降は 通常の LZW 法と同様の方法に戻る。（c）は 11 文字目 まで処理したときの辞書を示す. 10 文字目までを表す 符号は，0,1,1,2, [4]，4 となる。但し，[4] は文字列 長を表すとする．文字列長の表現方法については $\mathbf{3 . 4}$ で論じる。

図 4 注符号化法のアルゴリズムを示す．関数 NextChar（）は 1文字入力すると共に移動空の内容を更新 する.变数 $p h$ は, 入力に一致する文字列が移動空内に ある場合，その位置を表すために用い，window $[p h]$ はその位置の文字を表す。関数 Increment $(p h)$ は移動 空の位置 $p h$ の次の文字の位置を返し, 関数 OutputLength $(n)$ は文字列長 $n$ を符号化して出力する。 た，関数 IsChar (str) は，符号 $s t r$ が文字を表すかど うかを調べる.

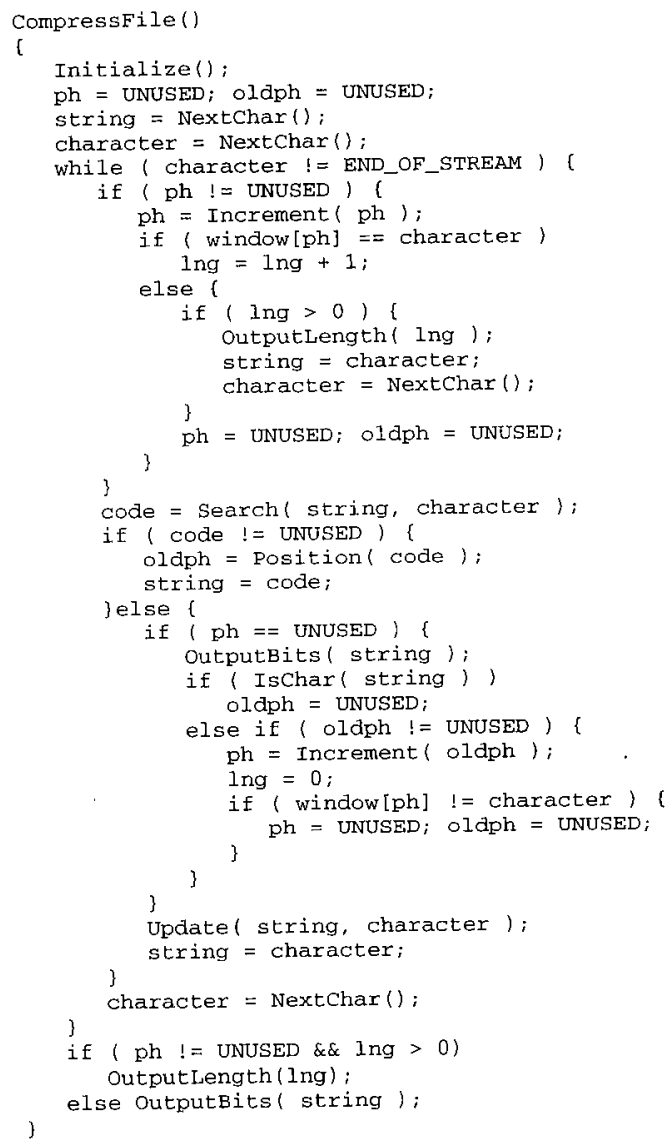

図 4 符号化アルゴリズム

Fig. 4 Coding algorithm.
このアルゴリズムは, 図 1 の LZW 法のアルゴリズ ムと比較すると，置換文字列との比較に関する場合分 けが行われているため，やや複雑になっている．但し このアルゴリズムは，LZW 法と同様に入力文字数に 対して線形時間で実行できる。

復号の際は，符号化のときと同じ LZW 辞書と移動 空を構築し， LZW 符号と置換文字列の長さを用いて 入力文字列を復元する. 置換文字列の移動空内の開始 位置は, 直前の $\mathrm{LZW}$ 符号と辞書の情報から一意に定 まる. 従って LZ 77 法に基づく多くの圧縮法とは異な り, 置換文字列の開始位置を符号化する必要はない.

\section{3 復号化について}

3.2 で述べたように，本方式では置換文字列に対し ても LZW のフレーズへの分解と辞書への登録を行 う. 置換文字列にこの操作を行わない場合, 压縮能力 が悪化することが実験の結果から判明している．従っ て, 復号化の処理におろても，得られた置換文字列を LZW のフレーズに分解し，辞書に登録するという操 作が必要になる。

LZW 法は復号化の際に，あるフレーズと文字の組 合せが既に辞書に登録されているかを検索して調べる 必要がなく，このことが復号化の高速化をもたらして

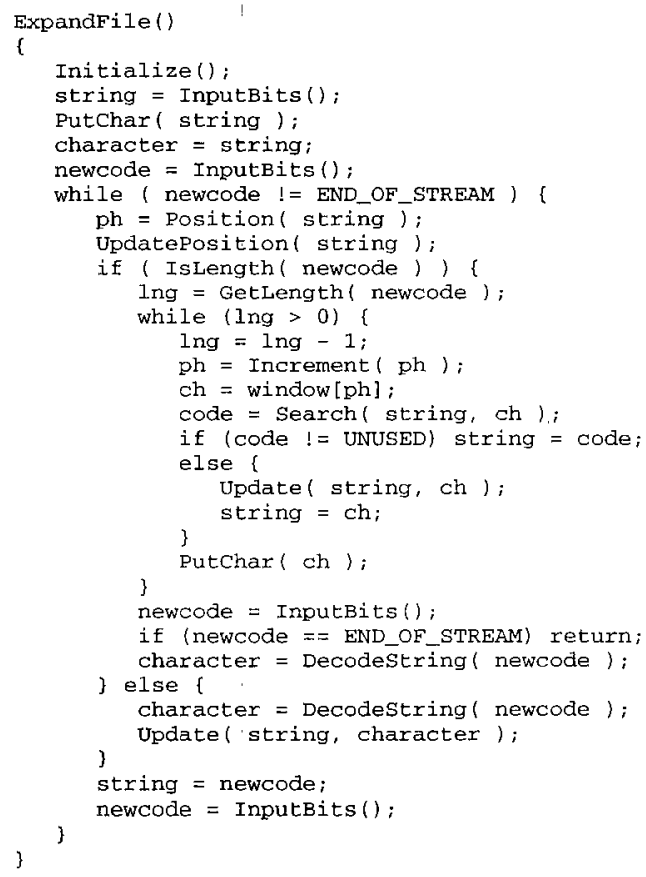

図 5 復号化アルゴリズム

Fig. 5 Decoding algorithm. 
いる．これに対し，本方式では復号化の際にも符号化 の際と同様な LZW 辞書と移動空を再構成する必要が ある.なお，横尾の符号をはじめ，LZW 法を改良した 方式には復号化の際に LZW 辞書を再構成する必要が あるものが多い。

図 5 に復号化のアルゴリズムを示す。この操作も入 力サイズに対する線形時間で行える.

関数 Position(str) 忤符号 str に対応するフレーズ の移動空内の位置を辞書から得る. 関数 UpdatePosition (str) は，符号 str を文字列に分解寸ると共に移動 空と LZW 辞書の内容を更新する。関数 IsLength (str)は，符号 $s t r$ が文字列長を表すかどうか調べ，関 数 GetLength $(s t r)$ はその長さを值とする。関数 DecodeString (str) は符号 str に対応する文字列を書 き出す.

\section{4 文字列長の表現}

図 4 に示したアルゴリズムでは，LZW 符号と置換 文字列の長さを具体的にどのように符号化して出力す るかに関しては記述していない。この実現にはさまざ まな方法が考えられるが，今回実験で作成したプログ ラムでは以下の二つの方法を用いた。

方法 (a) compress では LZW 符号は当初 9 ビッ トで表され，符号が大きくなるに従ってビット数を増 加させている，この方法では，符号を表すために使用

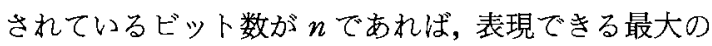
数 $M$ は $2^{n}-1$ である. その時点で最大の $\mathrm{LZW}$ 符号に 相当する整数值が $Z$ ならば， $(Z+1)$ から $M$ までの整 数は使用さ机ない. 置換文字列の長さ $L か ゙ ~ L<M-Z$ の場合, $(M-L)$ は $n$ ビットで表現され, LZW 符号と 区別できる。そこで, LZW 符号は compress と同じ方 法で表現し，置換文字列の長さは $(M-L)$ を出力する ことにする。但し， $L \geqq M-Z$ の場合には，ほかの LZW 符号と区別できる符号をあらかじめ用意してお き，この符号の直後に $L$ を出力する. 実験の結果では 大半の場合について前者の方法で符号化できている.

方法 (b) 置換文字列は, 短いものほど高い頻度で 出現する，そこで，これらの文字列長の平均よりも十 分大きな数 $S$ (以下の実験では $S=128$ とした）を決 め, 1 から $S$ までの置換文字列の長さを表すために $S$ 個の特別の符号をあらかじめLZW 辞書に含めてお

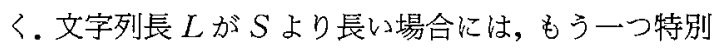
に用意した符号の直後に $L$ を出力する. 方法 (a) LZW 法の符号化方式にもともと存在していた冗長な 部分を利用していることになるが，この方法(b)では
その圥長さを残している.また, 初期状態の LZW 辞書 のサイズが大きくなるため，方法(a)よりは圧縮率が 亜い.

以下の実験では，特に断らない限り方法(a)を用い て性能評価を行う. 但し, 4.5 で方法 (a) と方法 (b)に ついて比較実験を行い, 置換文字列の長さを符号化す ることが LZW 法の改良になっていることを示す。

\section{4. 実験による性能評価}

\section{1 比較対象とした圧縮法について}

本論文の目的は，提案したアルゴリズムが LZW 法 の圧縮能力を改善していることを示すことである。そ こで，LZW 法とその改良である横尾の符号，および Bernstein の Y 符号を比較対象として取り上げる。ま た，LZ 77 法に基づく文字列置換による圧縮法の代表 として LZSS (Lempel-Ziv-Storer-Szymanski) 法(9) を 取り上げ,压縮の傾向などに関して比較検討を試みる.

ここで, LZW 法, LZSS 法のプログラムとして, 文 献 ( 2 )に揭げられたプログラムを使用した。 また，本 論文のアルゴリズムによるプログラムおよび横尾の符 号（文献 (6)でのアルゴリズム1）のプログラムはこ の LZW 法のプログラムに手を加えて実現している. LZW 法, 横尾の符号, および本方式のいずれのプログ ラムも，フレーズを表す符号があらかじめ定めた最大 ビット数で表現できなくなった時点で辞書を初期化す る方式を用いている．Y符号のプログラムは Bernsteinがネットワータ上经公開しているプログラム yabbaを用いた。

以下の説明および図表では, 最大ビット長が 14,16 の LZW 法をそれぞれ LZW 14, LZW 16 と呼が. 獚尾 の符号も同様にYok 14, Yok 16 とする. yabbaでは 使用するメモリのサイズを指定できるが，ここでは 16381 と 65533 を用小，それぞれyab 16, yab 65 と呼 ぶ.これらの辞書に登録できるフレーズ数はそれぞれ LZW 14, LZW 16 に対応する. LZSS 法ではリングバ ッファのサイズを 2 kByte, 8 kByte とし，それぞれ LZSS $2 \mathrm{k}$, LZSS $8 \mathrm{k}$ と呼ぶ. それぞれの先読みバッフ ア長は 17 Byte, 18 Byteである. 本方式のプログラム は $\mathrm{LZW}$ 辞書の最大ビット数とリングバッファの長さ の二つのパラメータをもつが, LZW 辞書の最大ビッ ト長が 14 でリングバッファ長が 2 kByteのプログラ ムをO 14-2 k のように㭔ら゙.

\section{$4.2 \mathrm{LZW}$ 辞書と移動空の大きさについて}

図 6 は, 本方式について LZW 辞書の最大ビット数 
と移動空の大きさを変化させたときの圧縮率の変化を 調べたものである．比較のために LZW 法の結果を加 えている。ここで，圧縮率＝(压縮後のサイズ/入力サ イズである.（a）のデー夕は UNIX 上のテキストエ ディタである emacsのソースプログラムおよび文書 類をUNIXのtarコマンドで一つのファイルにまと めたもの (10.0 MByte)，（b ）のデー夕は英語版聖書† (4.6 MByte) である.

LZW 辞書のサイズが小さい場合に, 移動空を付加 する効果が大きいことがわかる。

バッファ長を大きくとっても，ある程度以上の大き さになると，効果があまり現れないということもわか る.これには以下の二つの理由が挙げられる。

提案したアルゴリズムでは, LZW 辞書から移動空 への位置情報は，常に一番最近出現したフレーズを参 照するように更新される。これは，移動空の更新に伴 って位置情報が無効になるのをできるだけ防ぐためで ある.この結果, LZW 辞書からは移動空の新しい入力 の部分をより多く参照するようになり，西まり長いバ ッファを使っても効果が現れにくくなると考えられ る。

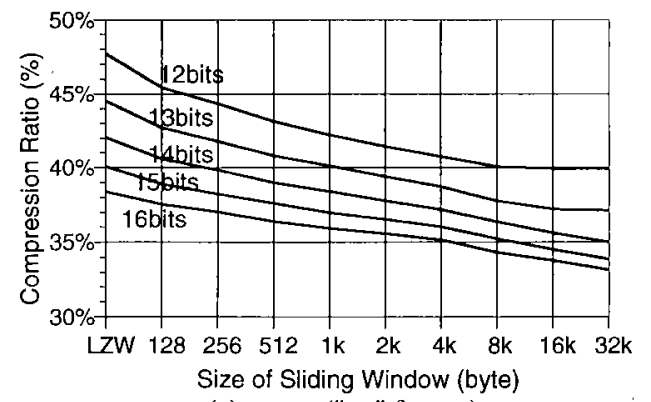
(a) emacs ("tar" format)

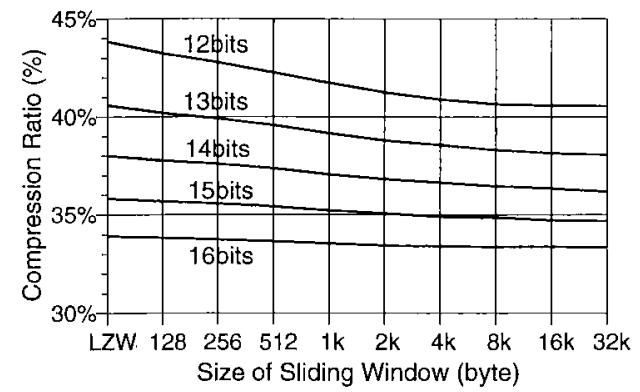

(b) Bible (plain text)

図 6 移動空のサイズと压縮率の変化

Fig. 6 Relation of sliding window size to compression ratio.
また，LZW 辞書のサイズに比べてバッファ長が大 きい場合，移動空の長さ分の情報を利用する前に LZW 辞書が飽和してしまうことがある，図 6 で最大 ビット数が 12 の場合，移動空の大きさを $8 \mathrm{kByte}$ よ り増やしても圧縮率の改善が見られないのはこのため であると考えられる。

\section{3 さまさまなデータによる比較}

図 7 は文献(1)で用いられている比較用データ外に 対する処理結果である。それぞれのデータの概要を表 1 に示す.

移動空の効果がはっきり現れるデータとそうでない データがあるが，一般に LZSS 法の圧縮率が良い場合 に移動空の効果も高くなる傾向がある．特にソースプ ログラムなどについて効果が著しい。移動空の効果が あまり出ていない場合でも，同じサイズの辞書をもつ LZW 法と同程度の結果を出している.

また，その他の方法と比較した場合，データによる 差異はあるものの,これらの中で最悪という例はない。 データの性質に左右されず，常に比較的良い圧縮率を 示している。

\section{4 入力長の変化による実験}

四 7 の結果からは，さまざまな入力長のデータに対 して圧縮率がどのように変化するかを知ることができ ない：そこで，次の方法で圧縮率の変化を測定した。 データとしては 4.2と同様, emacsのソースプログラ ムと聖書を用いる。 emacs ファイルについては先頭か

表 1 '比較用デー夕の内容

\begin{tabular}{l|l|r}
\hline データ名 & \multicolumn{1}{|c|}{ 内 } & \multicolumn{1}{c}{$\begin{array}{c}\text { 大きさ } \\
\text { (Kbyte) }\end{array}$} \\
\hline bib & 文献目録(refer形式) & 111.3 \\
book1 & 小説 & 768.8 \\
book2 & 論文(troff形式) & 610.9 \\
geo & バイナリデータ & 102.4 \\
news & 電子ニュース & 377.1 \\
obj1 & VAX実行形式 & 21.5 \\
obj2 & Macintosh実行形式 & 246.8 \\
paper1 & 論文(troff形式) & 53.2 \\
paper2 & 論文(troff形式) & 82.2 \\
pic & ビットマッブ & 513.2 \\
progc & Cブログラム & 39.6 \\
progl & Lispブログラム & 71.6 \\
progp & Pascalブログラム & 49.4 \\
trans & 画面操作シーケンス & 93.7 \\
\hline
\end{tabular}

$\dagger$ The King James' Bible, Project Gutenberg 2nd Version (1992).

† Data Compression Corpus. このデータは最近, 圧縮プログラムの 性能を評価するための標準的な゙゙ー夕として用いられている。ネッ トワーク経由で入手可能である。 


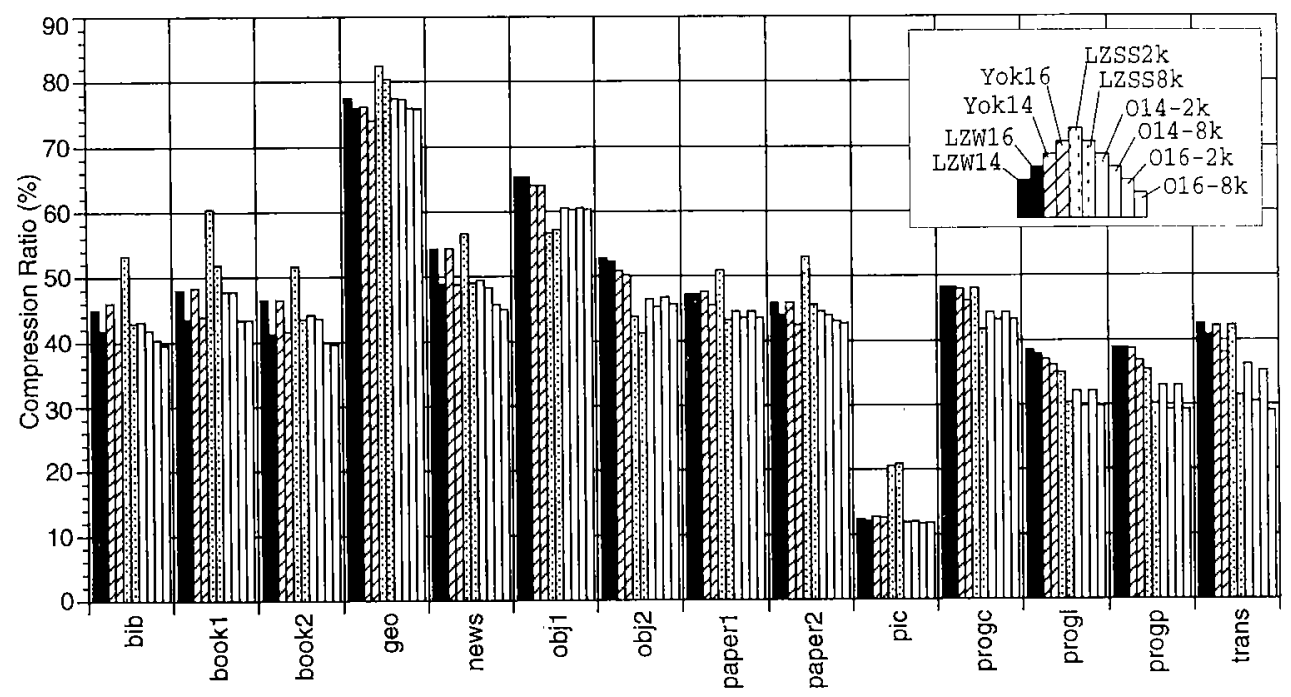

図 7 さまざまなデー夕による比較

Fig. 7 Comparison using various data.
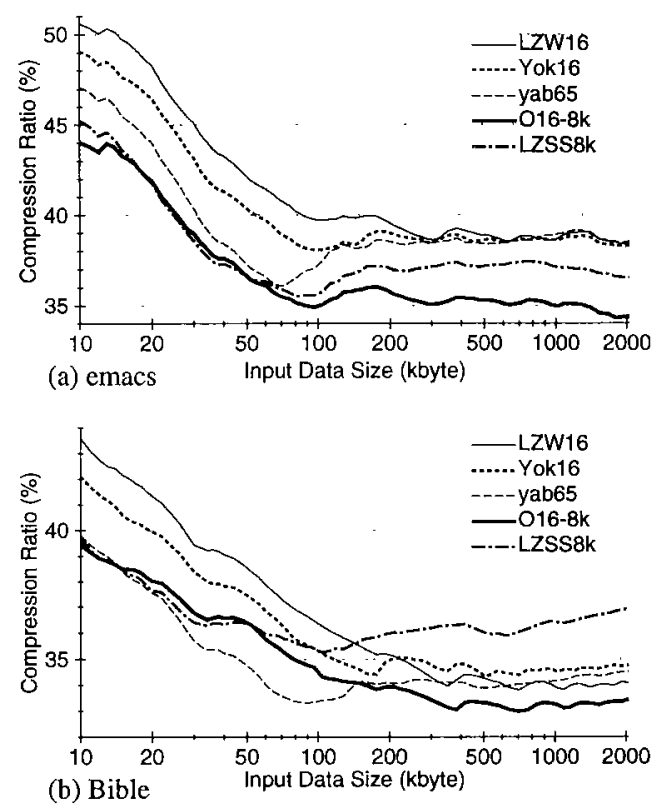

図 8 入力長による圧檽率の変化

Fig. 8 Relation of input data size to compression ratio.

ら 0,2,4,6,8 MByte, 聖書ファイルについては先頭か ら $0,0.5,1.0,1.5,2.0$ MByte $の$ 位置から始まる大き さ2 MByteのファイルを用意する。これら五つのファ イルのそれぞれについて，入力長が増加するのに伴う 圧縮率の変化を計測し，結果の平均を求めた。このよ
うにすれ梳，ファイルの特定の部分に依存するデー夕 の変動を少なくし，压縮法の特性を明らかにできる。

図 8（a）は emacsファイル，(b)は聖書ファイルに ついて, 入力長の変化に伴う各圧縮法の圧縮率の推移 の傾向を表す．本方式は入力サイズが小さいうちから 圧縮能力が高い.また，横尾の符号および $\mathrm{Y}$ 符号は， 入力サイズが小さい場合には LZW よりも高い圧縮能 力を示すが，入力サイズが大きくなって辞書が飽和す るようになると LZW とほほ同等の厈縮能力になると いう点も注目される。これらの例に見られるように， 移動空の効果が大きいデー夕に対しては，本方式は LZSS 法と似た特性を示し, 移動空の効果があまり出 ないデー夕に対して LZW 法と似た特性を示す。

\section{5 文字列長の符号化方法の比較}

これまでの実験では, 置換文字列の長さの符号化に 3.4 で述べた方法 (a) 用いていた. 方法 (a) は LZW 法の符号化方式にもともと存在していた冗長な部分を 利用しているため, 篅密には置換文字列の長さを符号 化することによって圧縮率を改善しているとは断言で きない.そこでこの長な部分を利用しない方法 (b) との比較を行った。なお，方法(b)で文字列長を表す ためにあらかじめ $\mathrm{LZW}$ 辞書に含める符号の数 $S$ は 128 とした。

図 9 は, LZW 辞書の最大ビット数が $12,14,16$ の場 合について移動空の大きさを恋化させ，対応する LZW 法の結果に対する大きさの割合を示したもので 


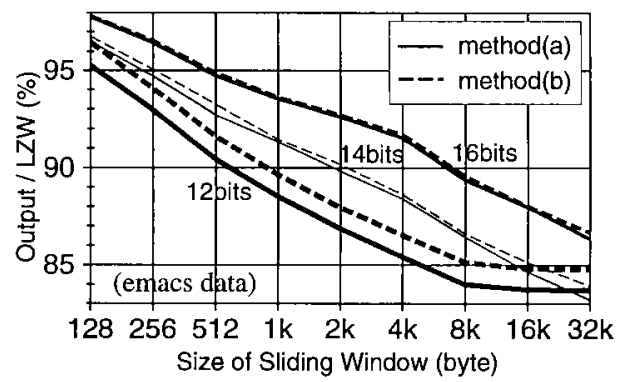

図 9 二つの符号化方式の比較：移動空のサイズ

Fig. 9 Comparison of coding methods: size of sliding windows.

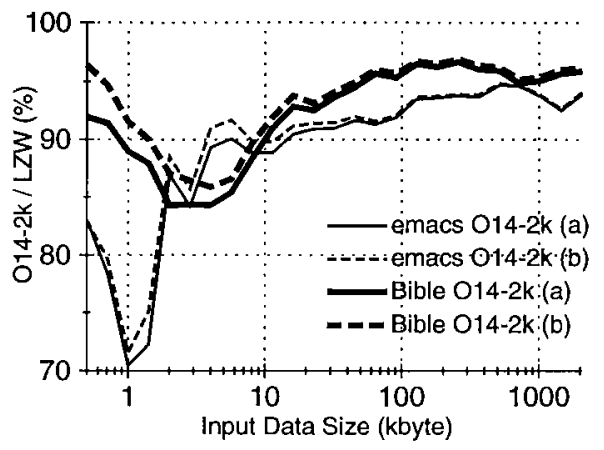

図 10 二つの符号化方式の比較: 入力サイズの変化

Fig. 10 Comparison of coding methods: input data size.

ある.データとしては emacs ファイルを用いた。 図中 の実線が方法 $(\mathrm{a})$ ，破線が方法 $(\mathrm{b})$ である.

図 10 は O 14-2k を使って, emacs デー夕, 聖書デ 一夕の先頭部分 2 MByte までのさまざまな大きさの デー夕を圧縮した結果と, 対応する LZW 14 の結果の 割合を表している.

これらの実験から，LZW 法の圥長な符号化方式を そのまま残した方法 (b)でも LZW 法の結果を改良し ていることがわかる。このことは，提案アルゴリズム が LZW 符号の代わりに置換文字列の長さを符号化す ることによって LZW 法を改良していることを示すも のである。

辞書の最大ビット数が小さい場合，および入力デー 夕が小さい場合に方法 (b)の圧縮率が徳いのは, LZW 辞書の初期サイズの大きさが影響しやすいためと考え られる。なお，方法 (b) 法，長法( a )との比較のため のものであり, $S=128$ という設定にも特に理論的な根 拠はない。また，その改良にはあまり意義を見出せな いが, 長い置換文字列の出現に従って長さを表す符号
表 2 処理時間の比較

\begin{tabular}{|l|c|c|}
\hline & \multicolumn{1}{|c|}{ 圧縮 } & 復元 \\
\hline LZW16 & $53.1(3.1)$ & $31.2(3.7)$ \\
O16-2k & $67.6(3.3)$ & $51.8(3.8)$ \\
O16-8k & $66.7(3.1)$ & $51.4(3.7)$ \\
Yok16 & $77.7(3.2)$ & $68.3(3.9)$ \\
LZSS8k & $345.6(4.2)$ & $26.2(3.5)$ \\
\hline
\end{tabular}

各櫩左はuser time (梨)，括弧内は system time(秒)である。

を動的に辞書に登録するなどの方法を採用すれば，上 記の問題点は解決可能であると思われる.

\section{6 ，実行時間}

4.1で述べたように，LZW 法，LZSS 法，横尾の符 号，および本アルゴリズムはすべて文献 (2)のプログ ラムに基づいて抢り，入出力部分は同一のルーチンを 使用している。これらのプログラムが聖書ファイルを 圧縮，および復元するのに要した実行時間を表 2 に示 す.このデータは NeXTstation Turbo 上で 5 回計測 したものの平均である.

本方式のプログラムが圧縮に要する時間は LZW 法 に比べ，25\%程度の増加にとどまっていることがわか る. 但し, 復元に要する時間は $60 \%$ 程度増加してしま う。これは, 3.3 で述べたように, LZW 辞書の再構成 とフレーズの検索が必要なためと考えられる。また， 移動空の大きさを変えても, 実行時間があまり変化し ないこともわかる、移動空が大きい方がわずかに速い のは，圧縮率の違いによって入出力データ量が減少し たためと考えられる。

\section{5. 議論}

\section{1 置換文字列の検索}

本方式では，LZW 法がフレーズとして切り出した 文字列のみを置換文字列の開始端の候補としている。 また，その候補はまったくないか，ある場合でも一つ だけという方法をとっている。しかしこの方法で，現 在の入力列と最も長く一致する置換文字列を移動空か ら検索できるわけではない.このことは, LZW 法が入 力列からフレーズを取り出すとき，そのフレーズの途 中から始まる文字列がフレーズとして辞書に登録され ないことから明らかである。

移動空の中から，現在の入力列と最も長く一致する 文字列を検索するという方法は LZSS 法などと同様, 検索にかなり手間がかかる．最良の置換文字列ではな くても, 複数の候補加らり長く一致する置換文字列 を選択するという方式もいくつか考无られる。しかし 
これらの場合には，置換文字列が移動空のどこにある かという情報も符号として出力に含めなければならな くなるため，圧縮能力が向上するかどうかは疑問であ る.

\section{$5.2 \mathrm{LZW}$ 法の改良アルゴリズムへの応用}

前述したように, 横尾の符号, Y 符号などでは LZW 法のフレーズの部分文字列を利用して新しいフレーズ を生成する。これらに本方式と同様の移動突を付加す ることも考えられょう。こうすれば，一定の大きさし かない移動空の中から置換文字列を見つける可能性を 高めることができるであろう。しかし反面，アルゴリ ズムの複雑化，処理時間の増加などが予想される。ま た，単に移動空を大きくとった場合よりも有効に働く かどうかは不明である。この問題に関しては引き続き 検討が必要である。

\section{3 連続する同一パターンの圧縮}

本方式では，入力文字列と置換文字列の比較をリン グバッファ上で行う。このため，同じ文字，あるいは 文字列が繰り返される場合には，入力文字が次々に置 換文字列として使われるという現象が見られ，圧縮効 率を非常汇高める効果がある．図 3 の例は，文字列 “abb”が連続する場合の例にもなっている。

同様な現象は LZSS法などでも見られるが，LZSS 法では先読みバッファの長さ以上の文字列は符号化で きないという制限がある。これに対して本方式は，リ ングバッファの長さにも関係なく，理論的にはパター ンがいくら長く連続しても非常に短い符号で表現する ことができる。この特徵から，本方式は同一のパター ンが連続して現れるデータの圧縮に効果があるものと 考えられる。

表 3 に例を示す．この実験で用いたデー夕は文字列 “yes”と改行文字の 4 文字の連続のみからなる。

\subsection{LZW 法と LZ 77 法の融合について}

インクリメンタル分解と文字列置換の融合による圧 縮法としては, 本論文のほかに横尾(10) の提案がある. 横尾は, 文献 ( 7 )の Algorithm 4, あるいは LZFG 法(8) を中心議論を行っているが, インクリメンタル分解 によるフレーズを表す符号の代わりに置換文字列の長

表 3 連続する文字列の圧縮

\begin{tabular}{|l|r|r|}
\hline Original & 512000 & 1024000 \\
\hline LZW16 & 2688 & 3946 \\
\hline Yok16 & 2185 & 3180 \\
\hline LZSS8k & 64008 & 128007 \\
\hline O16-8k & 16 & 16 \\
\hline
\end{tabular}

さを符号化するという基本的なアイデアは本論文と同 じである。

しかし，文献(10)では移動空を用いる方法に関して は論じられていない。本論文は, LZW 法と LZ 77 法の 融合に移動空を利用する具体的かつ実用的な実現の一 つであると言える。また，本論文では各種の実験を通 し、て，LZW 法と LZ 77 法の融合方式が LZW 法と LZ 77 法の特徵を併せもった圧縮特性を示すことを明 らかにした。

今, $x, y$ が文字, $X, Y$ が文字列を表し，また， $X y$ が文字列 $X$ に文字 $y$ を連接した文字列を表すものと する. LZW 法では, $X y$ がフレーズとして辞書に登録 されている場合， $X$ も必ず辞書に保存されている(条 件 1). 文献(10)で性これに加え， $x Y$ がフレーズとし て辞書に登録されている場合には $Y$ も辞書に保存さ れていること（条件2）を，融合方式のアルゴリズム が満たすべき条件として挙げている．これに対し，本 論文で提案した方法は LZW 辞書をもつことを仮定し ているだけであり，上記の条件 2 は必須ではない。こ のため, 辞書の構築を高速に行うことが可能である.

条件 2 が不要である理由としては, 本方式が過去の 入力系列を記憶するための手段として移動空を用いて いることと, 5.1 で論じたように, あるフレーズが参照 する移動空上の文字列位置を一つに限定していること が挙げられる．この意味において，本論文は横尾の提 案とやや異なるアプローチによる融合方式のクラスが 存在することを示すものと考劣られよう。

\section{6. むす び}

LZW 法に移動空を付加し, 文字列置換による符号 化を組み合わせる新符号化法を提案した. また, さま ざまなデータに対して適用実験を行った結果から, 本 方式は LZW 法の圧縮能力を改善すると共に, 処理速 度の面からも実用性の高い方式であることを示した。

今後は, 5.で述べたように, 他の LZW 法の改良アル ゴリズムへの適用実験，アルゴリズムの高速化，ちよ び融合方式に関するいっそうの考察が課題である。本 論文ではアルゴリズムと実験結果の報告を行ったが， 本方式朽よび融合方式に関しては，その性質をより体 系的に明らか比する必要があろう。

謝辞 本研究を行う上で, 常に励まして頂いた大阪 大学情報処理教育センターの福岡秀和教授, 松浦敏雄 助教授に深く感謝致します. 


\section{文献}

(1) Bell T. C., Cleary J. G. and Witten I. H. : "Text Compression", Prentice Hall (1990).

(2) Nelson M.: "The Data Compression Book", Prentice Hall (1991).

(3) Ziv J. and Lempel A.: "Compression of Individual Sequences via Variable-Rate Coding”, IEEE Trans. Inf. Theory, IT-24, 5, pp. 530-536 (Sept. 1978).

(4) Welch T. A.: "A Technique for High-Performance Data Compression", IEEE Computer, 17, 6, pp. 8-19 (June 1984).

(5) Ziv J. and Lempel A.: "A Universal Algorithm for Sequential Data Compression", IEEE Trans. Theory, IT-23, 3, pp. 337-343 (May 1977).

（6）横尾英俊：“実時間パターン照合によるデータ圧縮の高性 能実用算法”，情報処理学会論文誌，30，10，pp. 13091315(1989-10).

(7) Yokoo H.: "Improved Variations Relating the ZivLempel and Welch-Type Algorithms for Sequencial Data Compression", IEEE Trans. Inf. Theory, 38, 1, pp. 73-81 (Jan. 1992).

(8) Fiala E. R. and Greene D. H.: "Data Compression with Finite Windows", Commun. ACM, 32, 4, pp. 490-505 (April 1989).

(9) Storer J. A. and Szymanski T. G. : "Data Compression via Textual Substitution", J. ACM, 29, 4, pp. 928-951 (Oct. 1982).

（10）横尾英俊：“Ziv-Lempel 符号の瀜合方式によるデータ圧 縮”, 信学技報, IT92-135(1993-03).

(平成 5 年 2 月 24 日受付, 6 月 16 日再受付)

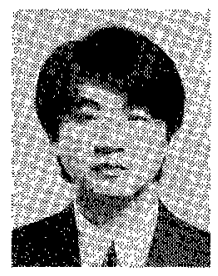

\section{荻原 剛志}

昭 60 山梨大·工・計算機科学卒. 昭 62 同 大大学院修士課程了. 平 2 阪大大学院博士 課程了．同年同大・情報処理教育センター 助手. ソフトウェアエ学, データ压縮など の研究に従事. 工博. 情報処理学会, 日本 ソフトウェア科学会各会員.

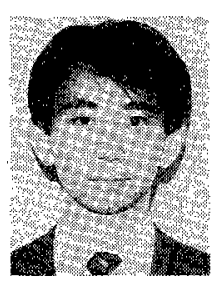

\section{飯田 元}

昭 63 阪大 - 基礎工・情報卒，平 2 同大大 学院博士前期課程了. 同年同後期課程入学. 平 3 同大・基礎工・情報・助手、ソフトウ エア開発プロセス肪よび開発支援環境の研 究に従事. 日本ソフトウェア科学会会員.

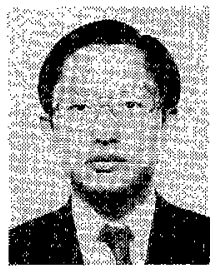

\section{井上 克郎}

昭 54 阪大 - 基礎工 - 情報卒. 昭 59 同大 大学院博士課程了. 同年同大 - 基碟工 - 情 報・講師. 昭 $59 \sim 61$ 八ワイ大学助教授. 平 3 阪大・基礎工・情報・助教授、ソフトウ エアプロセス, 関数型言語の処理系等の研 究に従事. 工博. 情報処理学会, ACM, IEEE 各会員.

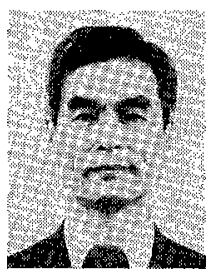

\section{鳥居 宏次}

昭 37 阪大 - 工・通信卒. 昭 42 同大大学 院博士課程了. 同年電気試験所 (現電子技 術総合研究所) 入所。昭 50 ソフトウェア部 言語処理研究室室長。昭 59 阪大・基礎工・ 情報・教授，平 3 奈良先端大・情報・教授 (阪大併任), 図書館長. 工博. ソフトウエ アメトリタスやフォーマルな開発プロセスなど, 定量的取扱い を中心とするソフトウェア工学に興味をもつ. IEEE Transaction on Software Engineering および IEEE Software 誌など の編集委員. IEEE, ACM, 情報処理学会各会員. 